\title{
Treatment of cerebral glioblastoma-caused bruxism with mirtazapine: a case report
}

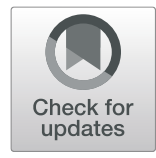

\author{
Mohsen Khosravi
}

\begin{abstract}
Background: Bruxism refers to grind or gnash the opposing rows of upper and lower molar teeth. It is important to treat bruxism as a factor that can influence sleep quality, quality of life, and mental status in patients with malignancy.

Case presentation: A 41-year-old male developed bruxism secondary to cerebral glioblastoma. L-dopa, gabapentin, clonazepam, clonidine, baclofen, buspirone, or propranolol were not effective. Mirtazapine, prescribed for side effects of chemotherapy, was effective for bruxism, which was disappeared within 3 weeks.
\end{abstract}

Conclusions: Mirtazapine was effective for treating bruxism as well as chemotherapy complications.

Keywords: Bruxism, Glioblastoma, Mirtazapine

\section{Background}

Bruxism is a repetitive masticatory muscle activity characterized by gnashing and grinding the teeth, and/or bracing, or thrusting mandible [1]. It has been demonstrated that bruxism has two circadian manifestations: sleep bruxism, and awake or diurnal bruxism [1]. According to fMRI evidence, diurnal tooth clenching is known to be related to activation of the bilateral sensorimotor cortex, supplementary motor area, dorsolateral prefrontal cortex, and the posterior parietal cortex [2]. This result suggests further evidence for a complex central mechanism involved in bruxism behavior [2]. Recent findings have shown that glioblastoma originated from the above-mentioned regions that can be involved in the incidence and pathogenesis of bruxism [3]. Furthermore, There is some evidence that chemotherapy may lead to or exacerbates bruxism [4]. The quality of life in such patients becomes increasingly important due to poor survival of this malignancy (14 months on average) [5, 6]. Therefore, it is important to treat bruxism as a factor that can influence sleep quality, quality of life, and mental status in these patients [7]. Although a range of drugs including muscle relaxants,

Correspondence: m.khosravi@zaums.ac.ir

Department of Psychiatry and Clinical Psychology, Baharan Psychiatric

Hospital, Zahedan University of Medical Sciences, Zahedan, IR 9813913777, Iran

\section{Springer Open}

sedatives anxiolytics, dopaminergic agents, and antidepressants has been suggested for pharmacological treatment [8], there have been no definitive treatments. We report a case of awake bruxism caused by the development of cerebral glioblastoma, which was successfully treated by a noradrenergic and specific serotonergic antidepressant, mirtazapine.

\section{Case presentation}

A 41-year-old male referred to our hospital was complaining of headache, amnesia, and left arm paresthesia. He also stated the onset of awake bruxism. He had been treated at a psychiatric clinic with a diagnosis of post-traumatic stress disorder after a terrorist attack and receiving risperidone, carbamazepine, citalopram, zolpidem, and melatonin. Brain MRI demonstrated a tumor $(34 \times 37 \mathrm{~mm})$ in the right frontal and parietal lobes accompanied with central necrosis and peripheral edema. A diagnosis of glioblastoma was made and he received radiotherapy and chemotherapy with temozolamide. L-dopa, gabapentin, clonazepam, clonidine, baclofen, buspirone, and propranolol were not effective for bruxism. Mirtazapine $15 \mathrm{mg} /$ day was started and increased to $30 \mathrm{mg} /$ day due to exacerbation of nausea, anorexia, insomnia, and amnesia following chemotherapy. It was effective for reducing the severity of bruxism as well as other symptoms. Bruxism (c) The Author(s). 2020 Open Access This article is licensed under a Creative Commons Attribution 4.0 International License, which permits use, sharing, adaptation, distribution and reproduction in any medium or format, as long as you give appropriate credit to the original author(s) and the source, provide a link to the Creative Commons licence, and indicate if changes were made. The images or other third party material in this article are included in the article's Creative Commons licence, unless indicated otherwise in a credit line to the material. If material is not included in the article's Creative Commons licence and your intended use is not permitted by statutory regulation or exceeds the permitted use, you will need to obtain permission directly from the copyright holder. To view a copy of this licence, visit http://creativecommons.org/licenses/by/4.0/. 
disappeared completely within 3 weeks and did not recur despite the enlarged tumor size after sessions of radiotherapy and chemotherapy $(38 \times 40 \mathrm{~mm})$.

\section{Discussion and conclusions}

Bruxism is the most frequently occurring oral movement disorder, and psychological factors and pathophysiological factors have been suggested as its etiologies [9]. Because the complications of bruxism, such as tooth wear, masticatory muscle pain, and insomnia significantly impairs the quality of life, prompt treatment is required. However, only a few controlled studies have been conducted for examining the effect of therapeutic agents [10]. Among antidepressants, amitriptyline and selective serotonin reuptake inhibitors (SSRIs) may exacerbate sleep bruxism [8]. On the other hand, there have been no data regarding the efficacy of other antidepressants including mirtazapine on bruxism [8]. In our patient, mirtazapine was effective for suppressing side effects of chemotherapy as well as bruxism. The effect of mirtazapine in the treatment of bruxism is related to unique mode of biochemical CNS action [11]. In fact, Mirtazapine increases dopaminergic neurotransmission in the prefrontal cortex by (1) 5 -HT2A and 5-HT2C receptors blockade, (2) 5-HT1A receptor activation, and (3) an elevation in noradrenaline levels, which may contribute to the effect in our patient $[12,13]$. This subject further reinforces the dopamine dysregulation hypothesis in the pathogenesis of bruxism [8].

In conclusion, mirtazapine was effective for treating bruxism as well as chemotherapy complications. However, wider investigations are necessary in this field through randomized controlled trials.

\section{Acknowledgements}

The author hereby thanks the patient, who aided in conducting the present case report.

\section{Authors'contributions}

The author wrote the draft of the manuscript and critical revisions and contributed to the writing of the manuscript. He approved the final manuscript.

\section{Funding}

No external funding supported this work.

Availability of data and materials

Not applicable

Ethics approval and consent to participate

Not applicable

Consent for publication

Written informed consent was obtained from the patient.

\section{Competing interests}

The author declares that he has no competing interests and/or publication of this article.
Received: 20 February 2020 Accepted: 12 March 2020

Published online: 21 March 2020

\section{References}

1. Lobbezoo F, Ahlberg J, Raphael KG, et al. International consensus on the assessment of bruxism: report of a work in progress. J Oral Rehabil. 2018; 45(11):837-44

2. lida T, Kato M, Komiyama O, Suzuki H, Asano T, Kuroki T, Kaneda T, Svensson P. Kawara M. Comparison of cerebral activity during teeth clenching and fist clenching: a functional magnetic resonance imaging study. Eur J Oral Sci. 2010;118(6):635-41.

3. Grant R. Medical management of adult glioma. In Management of Adult Glioma in Nursing Practice (pp. 61-80). Springer, Cham.2019.

4. Da Ponte G, Rato J, Pinto C, Lobo M, Ouakinin S. Bruxism as a consequence of chemotherapy? Eur Psych. 2017:41:S668.

5. Delgado-López PD, Corrales-García EM. Survival in glioblastoma: a review on the impact of treatment modalities. Clin Trans Oncol. 2016;18(11):1062-71.

6. Thier K, Calabek B, Tinchon A, Grisold W, Oberndorfer S. The last 10 days of patients with glioblastoma: assessment of clinical signs and symptoms as well as treatment. Am J Hos Palliative Med. 2016:33(10):985-8.

7. Câmara-Souza MB, de Figueredo OMC, Garcia RCMR. Association of sleep bruxism with oral health-related quality of life and sleep quality. Clin Oral Invest. 2019;23(1):245-51.

8. Alóe F. Sleep bruxism treatment. Sleep science. 2009;2(1):49-54.

9. Lobbezoo F. Taking up challenges at the interface of wear and tear. Journal of dental research. 2007 Feb;86(2):101-3.

10. Pierce CJ, Gale EN. A comparison of different treatments for nocturnal bruxism. J Dent Res. 1988 Mar;67(3):597-601.

11. Anttila SA, Leinonen EV. A review of the pharmacological and clinical profile of mirtazapine. CNS drug reviews. 2001:7(3):249-64.

12. Nakayama K, Sakurai T, Katsu H. Mirtazapine increases dopamine release in prefrontal cortex by 5-HT1A receptor activation. Brain Res Bull. 2004;63(3): 237-41

13. Millan MJ, Gobert A, Rivet JM, Adhumeau-Auclair A, Cussac D, NewmanTancredi A, Dekeyne A, Nicolas JP, Lejeune F. Mirtazapine enhances frontocortical dopaminergic and corticolimbic adrenergic, but not serotonergic, transmission by blockade of a2-adrenergic and serotonin2C receptors: a comparison with citalopram. Eur J Neurosci. 2000;12(3):1079-95.

\section{Publisher's Note}

Springer Nature remains neutral with regard to jurisdictional claims in published maps and institutional affiliations.

\section{Submit your manuscript to a SpringerOpen ${ }^{\odot}$ journal and benefit from:}

- Convenient online submission

- Rigorous peer review

- Open access: articles freely available online

High visibility within the field

- Retaining the copyright to your article

Submit your next manuscript at $>$ springeropen.com 